\title{
7. A NEW BIOSTRATIGRAPHIC INTERPRETATION OF THE SEDIMENTARY RECORD RECOVERED AT SITE 462, LEG 61, NAURU BASIN, WESTERN EQUATORIAL PACIFIC ${ }^{1}$
}

\author{
Isabella Premoli Silva, Dipartimento di Scienze della Terra, Universitá di Milano²
}

\begin{abstract}
Reinterpretation of the biostratigraphic record from Hole 462, drilled in the Nauru Basin during Leg 61, emphasizes the importance of larger foraminifers in dating heavily redeposited sequences. Younger ages derived from larger foraminifers are supported by the occurrence of some planktonic marker species (foraminifers and radiolarians) previously interpreted as downhole contaminants. A major implication of the new younger ages is that the main erosional events previously dated at $37 \mathrm{Ma}, 32 \mathrm{Ma}, 26 \mathrm{Ma}$, and $13 \mathrm{Ma}$ now have an age of $30 \mathrm{Ma}, 28 \mathrm{Ma}, 26 \mathrm{Ma}$ or younger, and $12 \mathrm{Ma}$, respectively. Erosional events at the end of the Eocene and within the early Oligocene can no longer be documented.
\end{abstract}

\section{INTRODUCTION}

Two holes were drilled at Site 462 in the Nauru Basin during Leg 61 in 1978 by the Glomar Challenger. Hole $462 \mathrm{~A}$ was reentered four years later in 1982 during Leg 89 in order to reach deeper horizons within the basaltic complex. The aim of this chapter is to reinterpret the biostratigraphic record from Hole 462, which was strongly biased by severe reworking and displacements of almost all the age-diagnostic fossil groups (Larson, Schlanger, et al., 1981), in light of a synthesis of the available data from both holes.

\section{DISCUSSION}

The sedimentary sequence recovered at Site 462 (Holes 462 and $462 \mathrm{~A}$ ) overlying the basaltic complex is characterized by pelagic clay and more rarely by radiolarian ooze, the autochthonous sediments, which alternate with carbonate-rich layers. Pelagic clay is dominant in the lower portion of the sequence from 550 to $450 \mathrm{~m}$ sub-bottom (Cores $462-59$ to $462-48$ ), then it decreases upwards. In the Cenozoic, from $370 \mathrm{~m}$ to the top of the hole (Cores $462-39$ to $462-1$ ), the amount of pelagic clay and/or radiolarian ooze is about $10 \%$ of the total thickness.

All the fossiliferous components, except the deep-dwelling agglutinated benthic foraminifers and possibly some radiolarians, have been transported. As a result, chronostratigraphy was jeopardized by reworking (Premoli Silva and Sliter, 1981; Premoli Silva and Violanti, 1981; Sanfilippo et al., 1981; Thierstein and Manivit, 1981). In the absence of age-diagnostic fossils from the autochthonous layers, the sediments were dated on the basis of the youngest components occurring in the various resedimented layers. However, under such conditions it is possible that even the youngest elements of a given fauna and/or flora could be not only displaced but also re-

\footnotetext{
${ }^{1}$ Moberly, R., Schlanger, S. O., et al., Init. Repts. DSDP, 89: Washington (U.S. Govt. Printing Office).

2 Address: Dipartimento di Scienze della Terra, Universitá di Milano, Via Mangiagalli, 34, 20133, Milan, Italy.
}

worked. Consequently, the resulting dates could be much older than the actual age of deposition.

Ages reported in the Site 462 report for Hole 462 samples and in several other chapters as well (Larson, Schlanger, et al., 1981) were based mainly on planktonic foraminifers and calcareous nannofossils. Discrepancies in the ages inferred from the different fossil groups are striking (see tables 4 and 5 in Larson, Schlanger, et al., 1981, pp. 52-53). Further discrepancies are evident if one compares the age inferred from the planktonics to those ages suggested by the shallow-water larger foraminifers (Premoli Silva and Brusa, 1981).

Most of the larger foraminifers are known to possess a high level of biostratigraphic resolution. Evolutionary lineages have been recognized within numerous, rapidly evolving genera. Moreover, each step within a lineage is identified as a species. Lineages are well dated by detailed quantitative studies and calibrated against stratotypes (i. e., the Lepidorbitoides lineage). In some cases, their occurrence could be correlated with the planktonic foraminiferal zonation schemes (van Gorsel, 1978; Adams, 1967; Schaub, 1951, 1981; Brönnimann, 1954; Haak and Postuma, 1975). Most of the species have a short stratigraphic range, and are diagnostic of specific time intervals. Furthermore, correctly identified specimens of a given evolutionary stage are age-diagnostic, even when recovered from a noncontinuous sequence. Thus the ages inferred from most of the larger foraminifers are as reliable as those based on planktonic foraminifers, once the calibration of a lineage is established.

At Site 462, although the shallow-water larger foraminifers are displaced in deeper water as are the calcareous plankton and most of the radiolarians, the taxa found give younger minimum ages than did previous age assignments that used planktonic organisms. The younger ages, based on the occurrence of some larger foraminifers from Hole 462, are as follows (from bottom to top) (see Fig. 1):

- Cores 462-52 and 462-51 contain numerous specimens of Vaughanina cubensis, which is Maestrichtian species according to Brönnimann (1954). Following Brönnimann's interpretation, Pseudorbitoides israelskyi among 


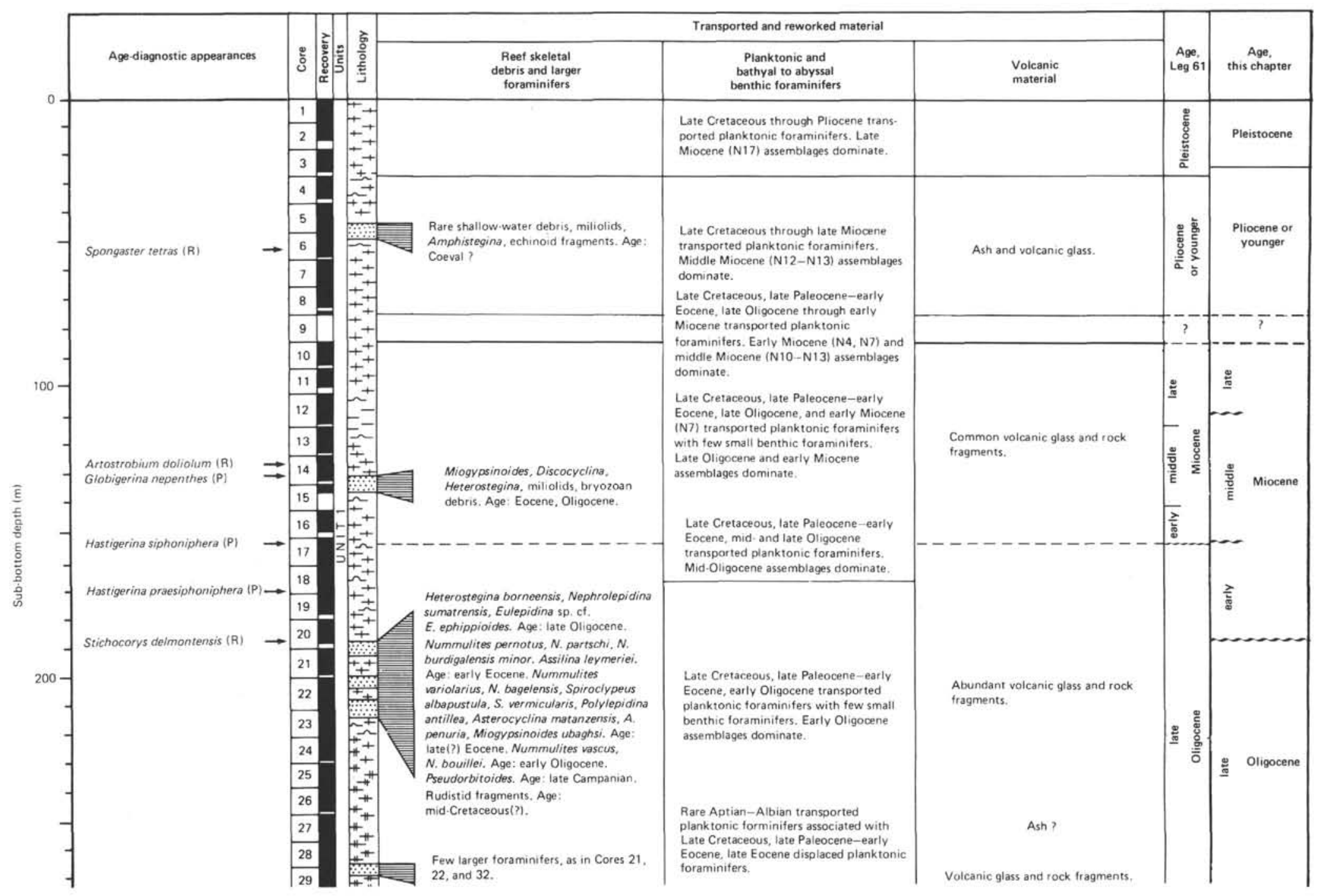




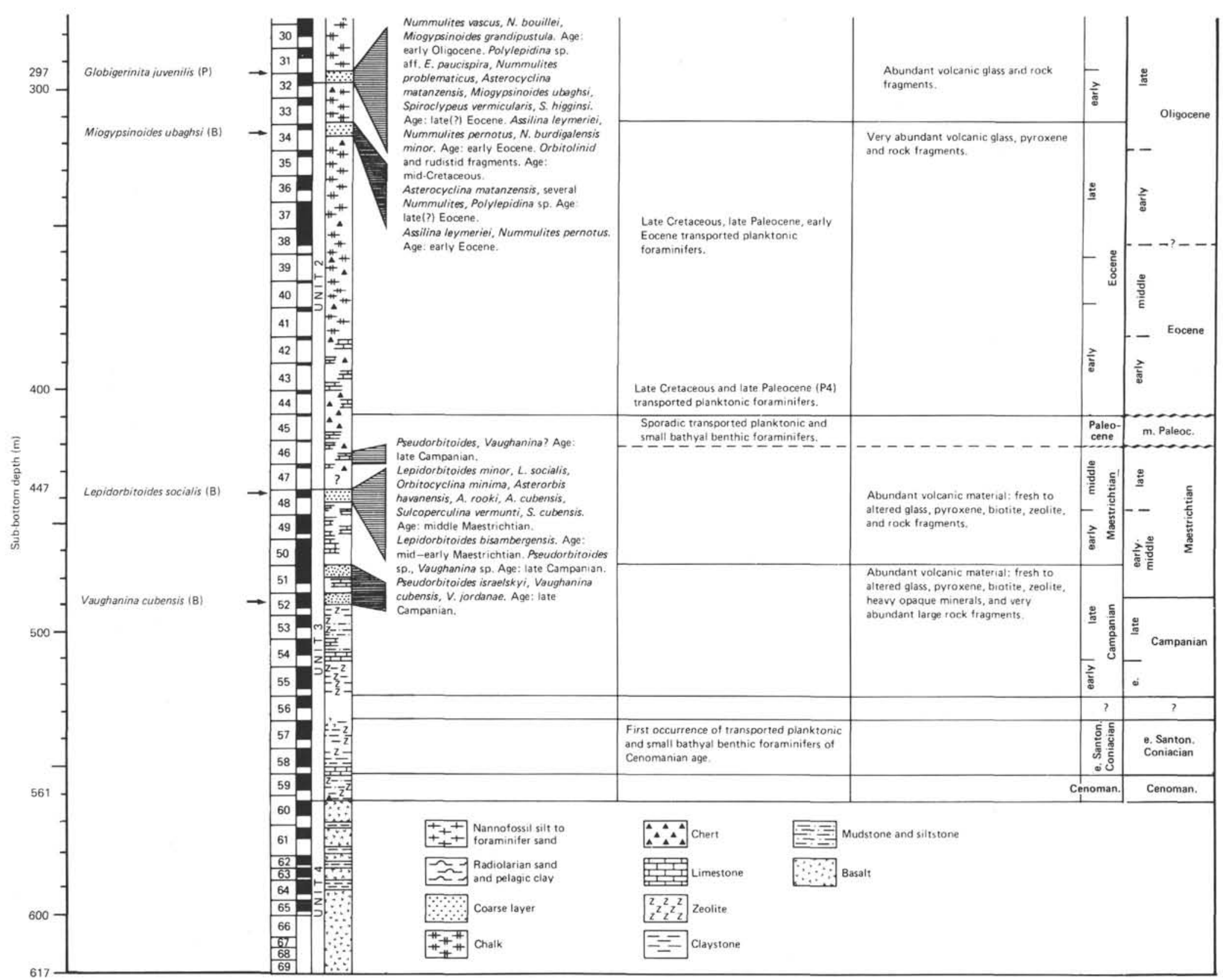


the larger foraminifers, and the planktonic foraminifers attributed to the Globotruncana subspinosa and Globotruncana calcarata Zones, all diagnostic for the late Campanian, are reworked. The above-mentioned cores are thus dated as Maestrichtian and not late Campanian, as previously reported (Larson, Schlanger, et al., 1981).

- Core 462-48 must be dated as late Maestrichtian based on the occurrence of Lepidorbitoides socialis, the end member of the Lepidorbitoides lineage (van Gorsel, 1978), and not as middle Maestrichtian, as inferred from the planktonic foraminifers attributed to the Globotruncana gansseri Zone. It is worth mentioning that the biostratigraphic signal from the calcareous nannofossils speaks in favor of an even older age (Thierstein and Manivit, 1981).

- Core 462-34 contains a few specimens positively identified as Miogypsinoides ubaghsi (Premoli Silva and Brusa, 1981). This genus is known to appear in the late Oligocene (Zone P21a = Globorotalia opima opima). Thus all the planktonic components that are diagnostic of the late Eocene are reworked.

- Section 462-32-1, again, contains representatives of Miogypsinoides. It must be dated at least to Zone P21a of the late Oligocene as was Core 462-34, or even younger. The planktonic foraminiferal assemblage of Zone P20 (= Globigerina ampliapertura Zone) is considered reworked.

On the basis of this age reinterpretation, some planktonic foraminifers that had been interpreted by Premoli Silva and Violanti (1981) as downhole contaminants may in fact represent a correct record. The previously interpreted contaminants that have now been reinstated as markers are (from bottom to top, see Fig. 1):

- Globorotalia opima opima, G. siakensis, well developed globoquadrinids, Globigerina ciperoensis, and large Globoquadrina tripartita occur in several samples from Core 462-34. Their presence is consistent with the late Oligocene of Core 462-34 inferred from the occurrence of Miogypsinoides. Moreover, some specimens of Globorotalia kugleri also occur in the same samples: if these forms are also proved to belong to the host fauna, then Core 462-34 should be dated as latest Oligocene. Because of its abundance in the upper part of the sequence, G. kugleri is still interpreted as a downhole contaminant.

- Some specimens of Globigerinita juvenilis occur in Sample 462-32-1, 73-75 cm. In the Atlantic this species appears within the range of Globigerina angulisuturalis (Zones P21b through P22) (author's personal observation, 1984; Bolli, 1957). This occurrence would confirm not only the late Oligocene age based on the presence of Miogypsinoides (see above), but would also indicate that Core 462-32 is younger than Core 462-34, as expected.

- Rare specimens of Hastigerina praesiphoniphera are recorded in Sample 462-18-6, 25-27 cm. According to Blow (1969), this species appears within the early Miocene Zone N7. Consequently, the Oligocene/Miocene boundary does not fall within Core $462-17$, as stated in the Site 462 report (Larson, Schlanger, et al., 1981) and in Premoli Silva and Violanti (1981).
- The subsequently recorded occurrences of Hastigerina siphoniphera in Sample 462-17-1, 6-8 cm, of Streptochilus pristinum in Sample $462-16-5,40-41 \mathrm{~cm}$, of Sphaeroidinellopsis subdehiscens, of evolutionary forms transitional to Globigerina nepenthes in Sample 462$15, \mathrm{CC}$, and finally of true Globigerina nepenthes in Sample 462-14-4, 86-87 cm allow us to state that the middle Miocene interval from the top of Zone N12 to Zone N14 is fully represented by Section 462-17-1 through Core 462-14. In particular, Cores $462-17$ and $462-16$ are younger than the early Miocene previously reported.

Besides the abundant reworking of the radiolarian faunas, Sanfilippo et al. (1981, p. 495) reported anomalous first appearances of some radiolarian species within the Cenozoic sequence from Hole 462; in particular, these authors stated:

(1) The first appearance of Podocyrtis ampla ampla and $P$. ampla fasciolata is abnormally late in the Cenozoic sequence.

(2) The first appearance of Thyrsocyrtis bromia and Calocyclas turris is abnormally early in relation to the first appearance of Theocampe pirum, the Lithocyclia aristotelis group, Thyrsocyrtis tetracantha, and Carpocanistrum azyx.

(3) The first appearance of Stichocorys delmontensis and Artostrobium doliolum is abnormally early.

(4) The isolated, abnormally early appearance of Siphocampe corbula, Dictyocoryne ontongensis, and Spongaster tetras in Sample 462-15,CC can be explained only by downhole contamination.

In view of the new foraminiferal data some anomalous occurrences can be reinterpreted as follows (see Riedel and Sanfilippo, 1978) (Fig. 1):

- $S$. delmontensis from Core 462-20-4, 25-27 cm may belong to the autochthonous assemblage that results in an early Miocene date for Core 462-20. The Oligocene/ Miocene boundary, then, would be placed between Cores 462-20 and 462-21.

- The occurrence of A. doliolum in Sample 462-14-2, $86-88 \mathrm{~cm}$ is in agreement with the middle Miocene age inferred for this core from planktonic foraminifers.

- Finally, if occurrence of S. tetras in Sample 462$15, \mathrm{CC}$ is the result of downhole contamination, then the appearance of $S$. tetras in Sample 462-6-3, 65-67 cm is in agreement with the Pliocene age (or younger) inferred from the appearance of Globorotalia margaritae in Core 462-7, the index species for the early Pliocene (Premoli Silva and Violanti, 1981).

The other anomalous occurrences mentioned by Sanfilippo et al. (1981) may be related to reworking similar to that of planktonic foraminifers.

Figure 2 shows the new age interpretations plotted against those reported in Larson, Schlanger, et al. (1981). It appears that ages derived from calcareous nannofossils are consistently older than those based on planktonic foraminifers and radiolarians.

The reinterpretation of the planktonic foraminiferal faunas emphasizes the importance of larger foraminifers as biostratigraphic indicators. In particular, at Hole 462 they are more reliable than planktonic foraminifers 
in dating heavily redeposited sequences. A possible explanation is that the age-diagnostic planktonic faunas are too diluted by reworked faunas to be perceived during a routine biostratigraphic observation. In contrast, the shallow-water components, being displaced suddenly by exceptional events, were not significantly contaminated.

The main consequences of the younger ages now reported from the interval from Cores 462-34 to $462-14$ are that (1) the accumulation rates plotted in table 1 by Premoli Silva and Violanti (1981) must be recalculated as reported in Table 1, and (2) the erosional events previously dated at $37 \mathrm{Ma}, 32 \mathrm{Ma}, 26 \mathrm{Ma}$, and $13 \mathrm{Ma}$ now have an age of $30 \mathrm{Ma}, 28 \mathrm{Ma}, 26 \mathrm{Ma}$ or younger, and 12 $\mathrm{Ma}$, respectively. The erosional event at the end of the Eocene and within the early Oligocene can no longer be documented.

\section{REFERENCES}

Adams, C. G., 1967. Tertiary foraminifera in the Tethyan, American, and Indo-Pacific Provinces. System. Ass. Publ., 7:195.

Blow, W. H., 1969. Late middle Eocene to Recent planktonic foraminiferal biostratigraphy. Proc. First Int. Conf. Planktonic Microfossils, Geneva, 1967, 1:199-422.

Bolli, H. M., 1957. Planktonic Foraminifera from the Oligocene-Miocene Cipero and Lengua formations of Trinidad, B. W. I. U.S. Nat. Museum Bull., 215:97-124.

Brönnimann, P., 1954. Upper Cretaceous orbitoidal foraminifera from Cuba. II. Vaughanina Palmer. Contrib. Cush. Found. Foraminif. Res., 5:91.

Haak, R., and Postuma, J. A., 1975. The relation between the tropical planktonic foraminiferal zonation and the Tertiary Far East letter classification. Geol. en Mijnbouw, 54(34):195.
Larson, R. L., Schlanger, S. O., et al., 1981. Init. Repts. DSDP, 61 : Washington (U.S. Govt. Printing Office).

Premoli Silva, I., and Brusa, C., 1981. Shallow-water skeletal debris and larger foraminifers from Deep Sea Drilling Project Site 462, Nauru Basin, Western Equatorial Pacific. In Larson, R. L., Schlanger, S. O., et al., Init. Repts. DSDP, 61: Washington (U.S. Govt. Printing Office), 439-473.

Premoli Silva, I., and Sliter, W. V., 1981. Cretaceous planktonic foraminifers from the Nauru Basin, Leg 61, Site 462, Western Equatorial Pacific. In Larson, R. L., Schlanger, S. O., et al., Init. Repts. DSDP, 61: Washington (U.S. Govt. Printing Office), 423-437.

Premoli Silva, I., and Violanti, D., 1981. Cenozoic planktonic foraminifer biostratigraphy of Deep Sea Drilling Project Hole 462, Nauru Basin (Western Equatorial Pacific), and distribution of the pelagic components. In Larson, R. L., Schlanger, S. O., et al., Init. Repts. DSDP, 61: Washington (U.S. Govt. Printing Office), 397-422.

Riedel, W. R., and Sanfilippo, A., 1978. Stratigraphy and evolution of tropical Cenozoic radiolarians. Micropaleontology, 23(1):61-97.

Sanfilippo, A., Westberg, M. J., and Riedel, W. R., 1981. Cenozoic radiolarians at Site 462, Deep Sea Drilling Project Leg 61, Western Tropical Pacific. In Larson, R. L., Schlanger, S. O., et al., Init. Repts. DSDP, 61: Washington (U.S. Govt. Printing Office), 495-505.

Schaub, H., 1951. Stratigraphie and Palaeontologie des Schlierenflysches. Schweiz. Palaeont. Abh., 68:108. 1981, Nummulites et Assilines de la Téthys paléogène. Taxinomie, phylogenése et biostratigraphie. Schweiz. Palaeont. Abh., 104:1-238, and atlas.

Thierstein, H. R., and Manivit, H., 1981. Calcareous-nannofossil biostratigraphy, Nauru Basin, Deep Sea Drilling Project Site 462, and Upper Cretaceous nannofacies. In Larson, R. L., Schlanger, S. O., et al., Init. Repts. DSDP, 61: Washington (U.S. Govt. Printing Office), 475-494.

van Gorsel, J. J., 1978. Late Cretaceous orbitoidal foraminifera. In Hedley, R. H., and Adams, C. G. (Eds.), Foraminifera (Vol. 3): London (Academic Press), 1-120.

Date of Initial Receipt: 16 November 1984 Date of Acceptance: 26 April 1985

Table 1. Recalculated accumulation rates of the Cenozoic sequence from Hole 462, Leg 61, according to the new age interpretations reported in Figures 1 and 2.

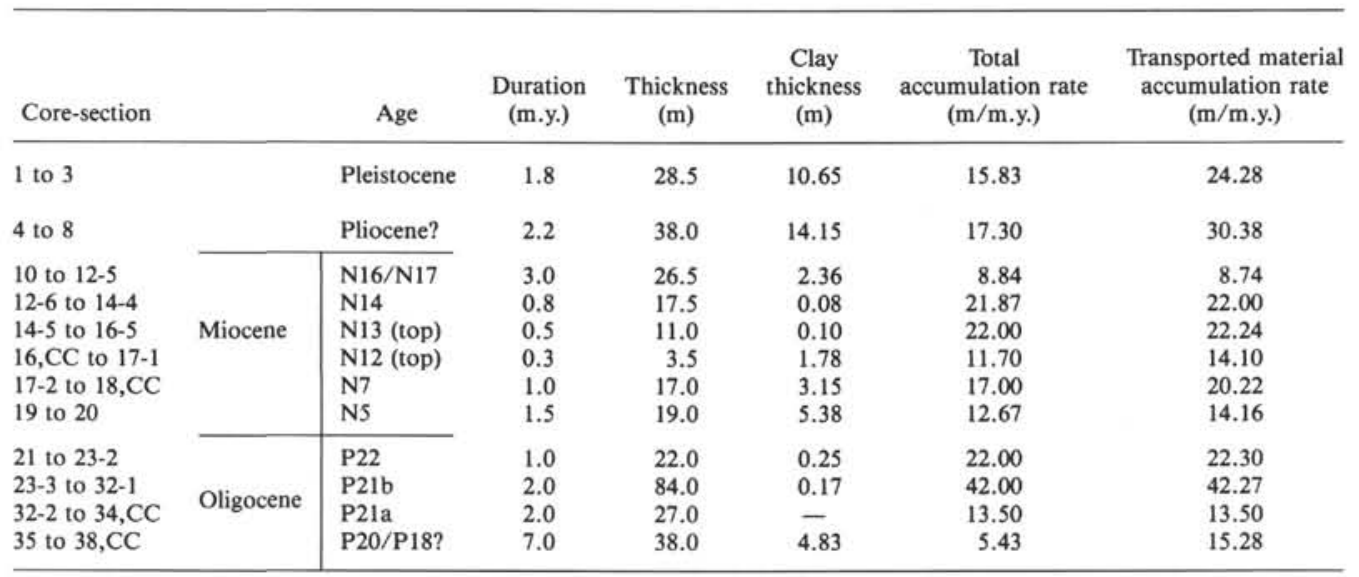


A.

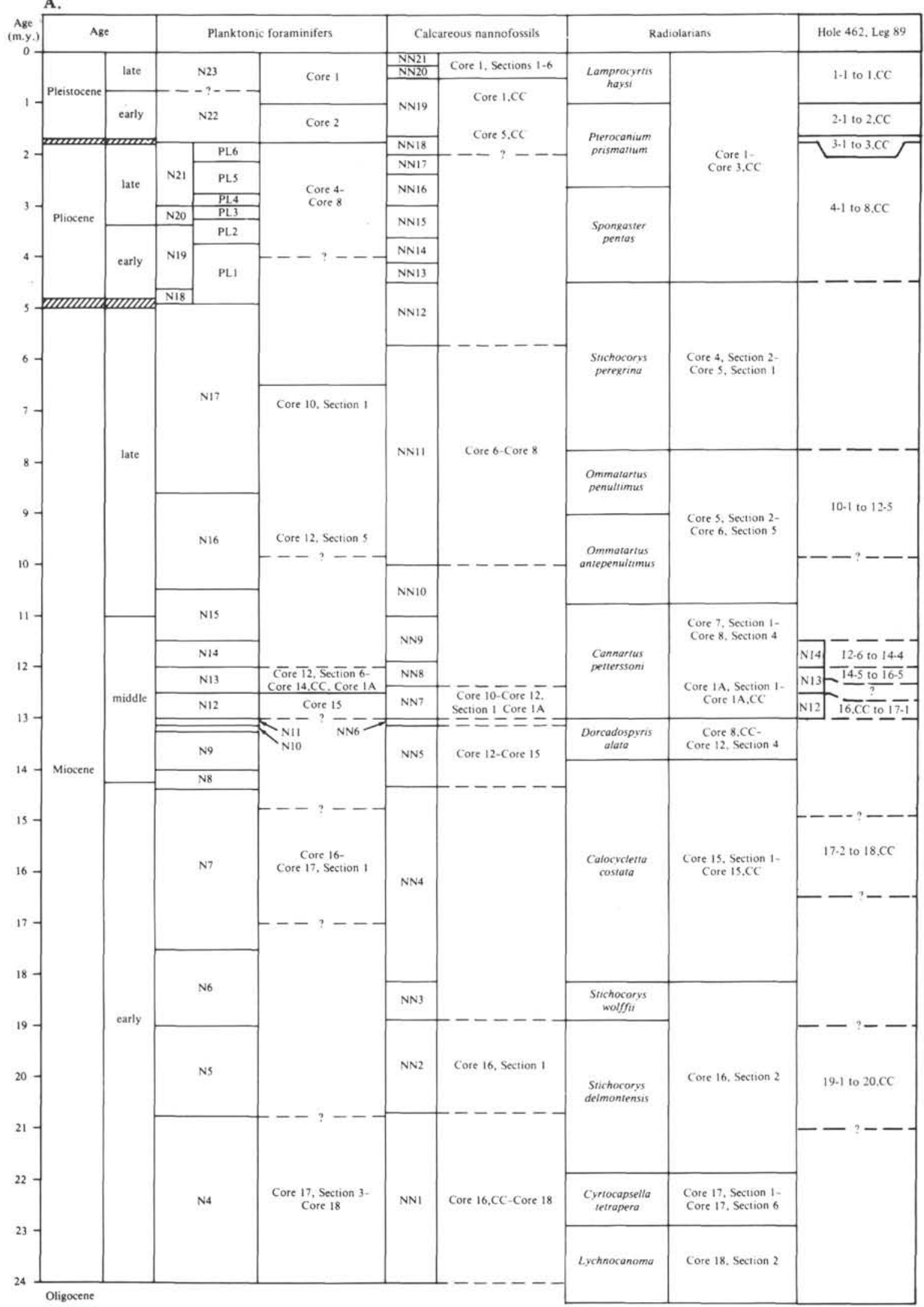

Figure 2. A-C. Neogene through Cretaceous biostratigraphy of Hole 462, Leg 61. Note the new age interpretations (last column) compared with those reported in Larson, Schlanger, et al. (1981). Hachured areas = uncertain boundaries. 
B.

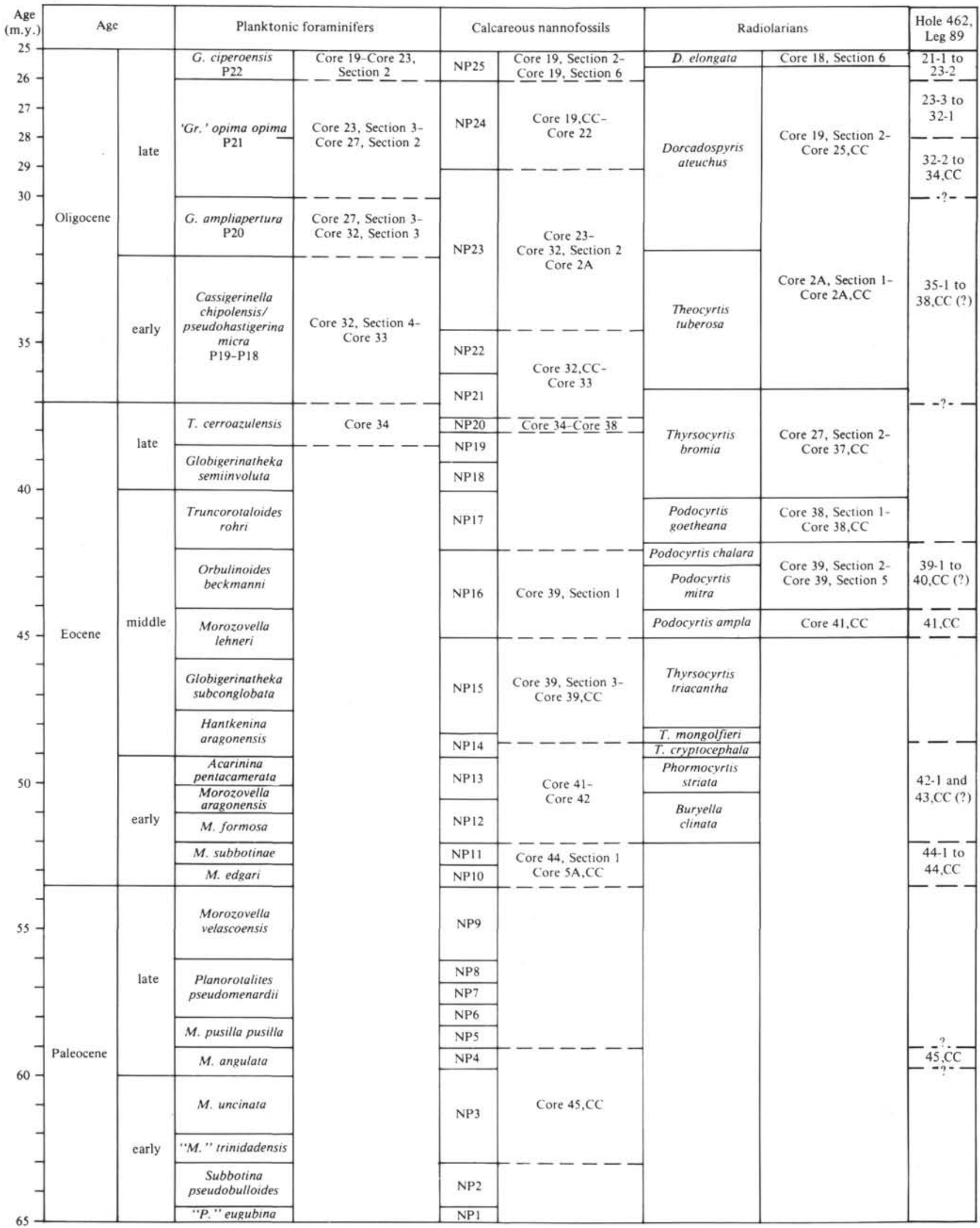

Figure 2 (continued). 


\section{PREMOLI SILVA}

C.

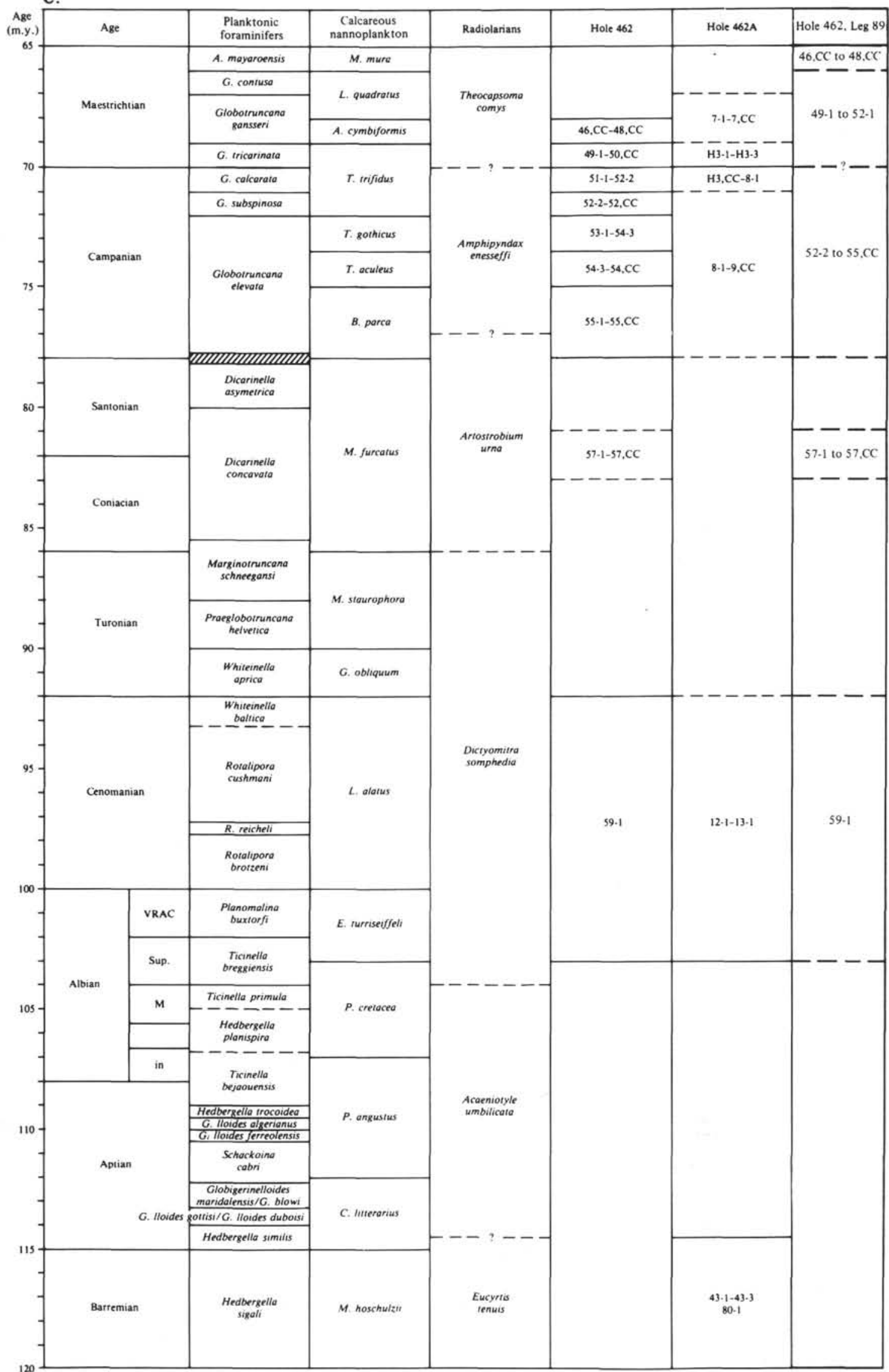

Figure 2 (continued). 


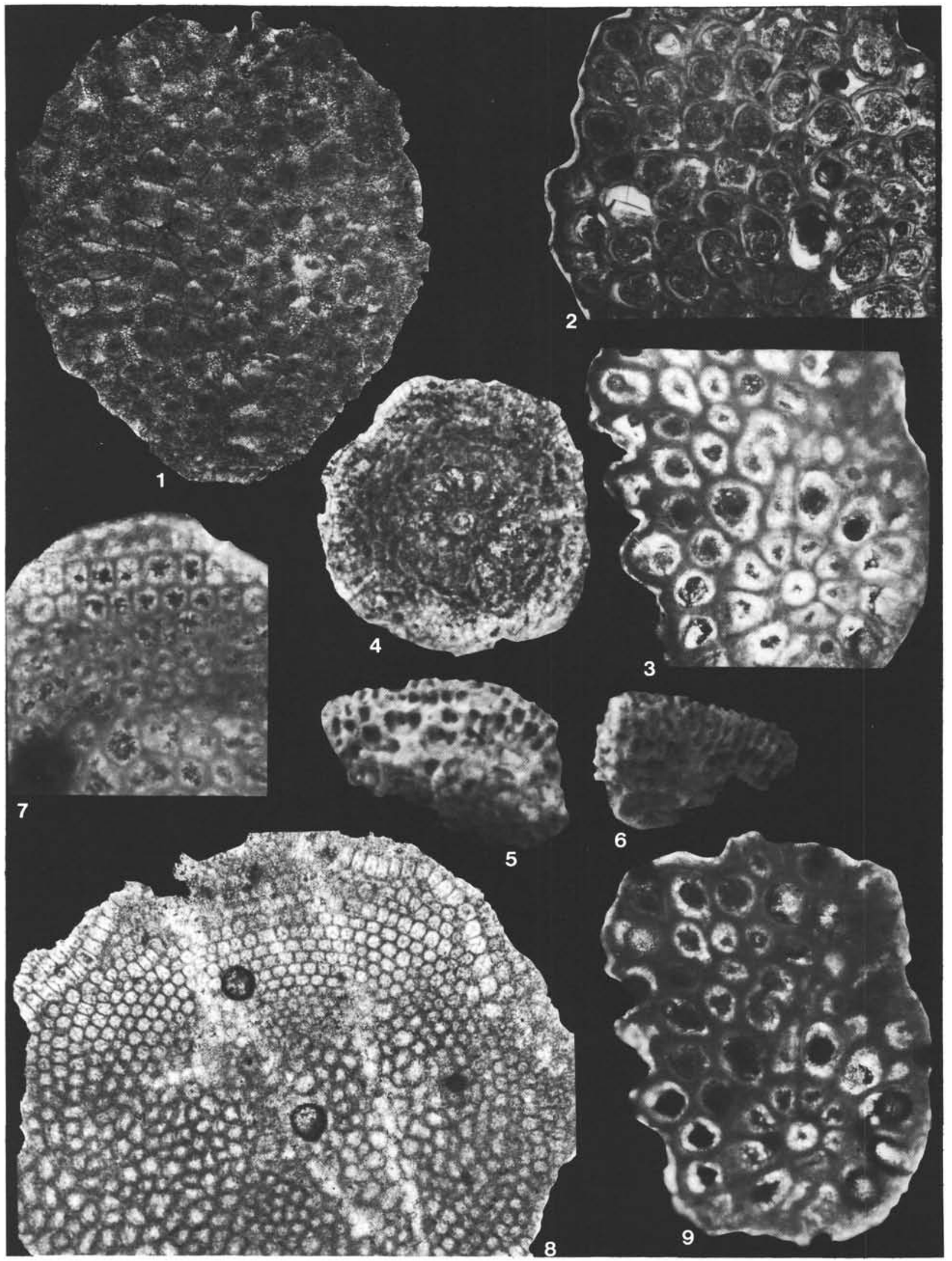

Plate 1. 1-3, 9. Miogypsinoides ubaghsi Tan. Sample 462-32-1, 5-10 cm, late Oligocene, (1) tangential section, $\times 75,(2)$ equatorial section, marginal portion, $\times 62$, (3) equatorial section, $\times 60$, (9) equatorial section, $\times 55$. 4-6. Vaughanina cubensis Palmer. Sample 462-52-1, 98-101 cm, Maestrichtian, (4) equatorial section, $\times 50,(5-6)$ fragments of the marginal portion, external view, $\times 60$. 7-8. Lepidorbitoides socialis (Leymerie). Sample 462-48 soup, late Maestrichtian, (7) detail of the marginal portion, equatorial section, $\times 190,(8)$ equatorial section, $\times 95$. 